\title{
Trends in Infant mortality rate and mortality for neonates born at less than 32 weeks and with very low birth weight ${ }^{1}$
}

\author{
René Mauricio Barría-Pailaquilén ${ }^{2}$ \\ Yessy Mendoza-Maldonado ${ }^{3}$ \\ Yohana Urrutia-Toro ${ }^{4}$ \\ Cristian Castro-Mora ${ }^{5}$ \\ Gema Santander-Manríquez ${ }^{6}$
}

The aim of the study was to assess the trend of the infant mortality rate between 19902004 and the neonatal mortality between 2000-2005 in infants born at less than 32 weeks of gestational age or with very low birth-weight. Based on secondary data, infant mortality rate and by its component for Valdivia city were compared with national indicators. Mortality at $<32$ weeks and $<1500 \mathrm{~g}$ was calculated, establishing causes of death and evaluating its relation with specific interventions, such as the use of surfactant and antenatal corticoids. Since the year 2000, infant mortality rates have stopped their decrease in comparison to the preceding decade and the gap between national and local rates before 2000 was drastically reduced. Mortality at $<32$ weeks and $<1500 \mathrm{~g}$ varied between $88 \%$ o and $200 \%$ o of liveborns, emphasizing respiratory distress as the main cause of death. The use of corticoids and surfactant was in line with reductions in mortality rates.

Descriptors: Infant Mortality; Neonatal Mortality; Premature; Infant, Newborn; Infant, Very Low Birth Weight.

\footnotetext{
${ }^{1}$ Supported by Dirección de Investigación y Desarrollo, Universidad Austral de Chile. Projecto DID S2007-59.

2 M.Sc., Researcher, Instituto de Enfermería, Universidad Austral de Chile, Chile. E-mail: rbarria@uach.cl.

${ }^{3}$ RN, Adjunct Professor, Instituto de Enfermería, Universidad Austral de Chile, Chile. E-mail: yessymendoza@uach.cl.

${ }^{4}$ RN, Unidad de Cuidado Intensivo, Clínica Alemana de Valdivia, Chile. E-mail: yohidata@hotmail.com.

${ }^{5}$ RN, Hospital Clínico Regional de Valdivia, Chile. E-mail: cristianrober@gmail.com.

${ }^{6} \mathrm{MPH}$, Director, Instituto de Enfermería, Universidad Austral de Chile, Chile. E-mail: gsantand@uach.cl.
}

Corresponding Author:

René Mauricio Barría Pailaquilén

Universidad Austral de Chile. Facultad de Medicina. Instituto de Enfermeria

Edificio Ciencias del Cuidado en Salud

$3^{\circ}$ Piso Campus Isla Teja.Valdivia, Chile

E-mail: rbarria@uach.cl. 


\title{
Tendência da mortalidade infantil e dos neonatos menores de 32 semanas e de muito baixo peso
}

Para avaliar a tendência da mortalidade infantil, entre 1990 e 2004, a mortalidade de prematuros < 32 semanas de idade gestacional e crianças de muito baixo peso ao nascer, entre 2000 e 2005, compararam-se dados secundários globais e por componentes do Serviço de Saúde Valdivia, e do total do país (Chile). Calculou-se a mortalidade específica em $<32$ semanas e $<1.500 \mathrm{~g}$, por mil nascidos vivos, estabelecendo causas de óbito e avaliando sua relação com intervenções específicas, como uso de surfactante e corticoides pré-natais. A mortalidade infantil deteve sua queda a partir do ano 2000, com referência à década precedente, e a brecha que existia, entre os valores nacionais e locais antes de 2000 , reduziu drasticamente. A mortalidade em $<32$ semanas e $<1.500 \mathrm{~g}$ variou entre 88 e $200 \%$ o nascidos vivos, destacando a síndrome da angústia respiratória como principal causa de morte. O uso de corticoides e surfactante coincidiu com reduções da mortalidade.

Descritores: Mortalidade Infantil; Mortalidade Neonatal; Prematuro; Recém-Nascido; Recém-Nascido de Muito Baixo Peso.

\section{Tendencia de la mortalidad infantil y de neonatos menores de 32 semanas y de muy bajo peso}

\begin{abstract}
Para evaluar la tendencia de la mortalidad infantil entre 1990-2004 y la mortalidad de prematuros menores de 32 semanas de edad de gestación y niños de muy bajo peso al nacer, entre 2000-2005, se compararon los datos secundarios globales por componentes del Servicio de Salud Valdivia con los totales del país, en Chile. Se calculó la mortalidad específica, por mil nacidos vivos, para los $<32$ semanas y $<1500 \mathrm{~g}$, estableciendo causas de muerte y evaluando su relación con intervenciones específicas, como el uso de surfactante y corticoides prenatales. Respecto a la década precedente, la mortalidad infantil detuvo su descenso a partir del año 2000 y la brecha existente entre los valores nacionales y locales previa al 2000 se redujo drásticamente. La mortalidad en los nacidos vivos con $<32$ semanas y $<1500 \mathrm{~g}$ varió entre $88 \%$ a $200 \%$, destacándose el síndrome de distrés respiratorio como la principal causa de muerte. El uso de corticoides y surfactante coincidió con las reducciones de la mortalidad.
\end{abstract}

Descriptores: Mortalidad Infantil; Mortalidad Neonatal; Prematuro; Recién Nacido; Recién Nacido de Muy Bajo Peso.

\section{Introduction}

The infant mortality rate (IMR) represents an important indicator of a country's wellbeing, given its relation with different factors, such as maternal health, quality and access to medical services, socioeconomic condition and public health policies. This reflects in the limited drops in mortality rates, in view of organizational problems in the National Health System and the periods of financial cuts in the public sector ${ }^{(1)}$.
As from the 1960's, the IMR has considerably decreased in Chile(2), thanks to the improvement in the population's general living conditions, including health service quality and accessibility, making the rate comparable to that of countries with high economic and social development levels ${ }^{(3)}$.

Out of 130 infant deaths that occur around the world every year, more than four million happen within the 
first four weeks of life. Three quarters of these deaths occur in the first week, and the first day of life represents the highest risk ${ }^{(4-5)}$. Focusing on this fact, perinatal and neonatal advances, together with increased resources to attack this problem, have permitted an increase in neonates' global survival(6). Neonatal mortality considers most infant deaths, proportionally increasing from 53\% in 1989 to $58 \%$ in 1998 . This increase is explained by the fact that, as a country reduces its IMR, mortality is increasingly influenced by non-avoidable causes, such as congenital malformations or chromosomopathies(6). In the same sense, in Chile, very low birth weight (less than $1500 \mathrm{~g}$ ), premature birth (less than 32 weeks of gestational age) and malformations are described as the main causes of neonatal death(7).

In the mortality context in children younger than 5 years, today, the neonatal component represents $38 \%$, reaffirming that, while the IMR is still decreasing, in response to the application of effective interventions (such as the immunization program), the proportion of neonatal deaths will increase ${ }^{(8)}$. Among interventions put in practice in Chile, the creation of neonatal intensive care units, the establishment of the national surfactant program as from 1998 and the premature follow-up program as from the year 2000 stand out(9), among others. To date, different child mortality studies have been published with a focus on distinct viewpoints (clinical, epidemiological, demographic, etc.), aiming to explain trends, causes and relations with specific factor and assessing the behaviors of its several components.

Having a primary approach to available information motivated us to study and look closer into the situation of premature infants in the context of a local tertiary referral center. Thus, this research aims to achieve two objectives:

- To present, with an aggregated approach (ecological), IMR behavior between 1990 and 2004, comparing the local and national evolution;

- To assess neonatal mortality, focusing on premature infants at less than 32 weeks and/or with very low birth weight between 2000 and 2005, and its relation with specific strategies put in practice or present during that period, such as exogenous surfactant and antenatal corticoid use.

\section{Methods}

Descriptive study of aggregated secondary data, with an ecological approach. Ecologic studies investigate rates for a disease or condition with regard to a factor described at population level. Consequently, analytic units are populations or groups of people instead of individuals ${ }^{(10)}$

The variables of interest were global and component IMRs for Chile and for the Valdivia Health Service (SSV), considering the period 1990 - 2004. For the period 2000 - 2005, the number of liveborns (LB) in the SSV, number of hospitalizations in the Neonatology unit of Hospital Clínico Regional Valdivia for infants at less than 32 weeks and/or with very low birth weight, surfactant and antenatal corticoid doses used per year were of interest. National infant birth and mortality statistics (by components and cause according to the International Classification of Diseases, ICD-10) for the period 19902004 (period with available data for health services) were used as information sources, obtained from the Department of Statistics and Information in Health (DEIS). To obtain local information for the period 2000 - 2005, the DEIS database of births and dysfunctions for the SSV was used, as well as the database of the Premature Follow-Up Program for children at less than 32 weeks and/or with very low birth weight at the SSV, statistical records of the hospital's Informatics and Computer Unit, drug dispatching records from the hospital's Pharmacy Unit and internal statistics from the Neonatology Unit. Similar data from different sources contrasted, choosing those data with as few missing data and/or inconsistencies as possible.

This paper is based on information obtained from the Research Project "Factors associated with neonatal, post-neonatal mortality and sequelae in premature infants at less than 32 weeks and/or with very low weight at birth, during the first year of life. Valdivia, 2000-2005", which received Institutional Review Board approval at Universidad Austral de Chile.

The analysis was based on a comparative assessment of the mortality trend between different local and national components, using DEIS reports. Described as such, the IMR refers to the number of deaths in infants younger than one year during a given year divided by the number of liveborns in the same year, multiplied by one thousand. Similarly, neonatal and early neonatal fractions are calculated for the remainder of the infant mortality components.

For local analysis of the premature group of interest (less than 32 weeks of gestational age and/or with very low birth weight), the mortality rate for 2000 - 2005 was calculated in function of the data the DEIS contributed for the SSV, considering both the Base of Births and that of Deaths. The indicator was constructed similarly to the above description. 
To assess the relation with the interventions under analysis, "surfactant use" and "antenatal corticoid use", the database of the hospital's Pharmacy Unit was used, analyzing doses dispatched per year for each drug and the calculated specific mortality rate.

\section{Results}

The comparative analysis of the national and SSV mortality trend for 1990 - 2004 showed important differences in all IMR components.

Globally, rates were higher for the SSV in almost all years, except for 1999 and 2004, although the trend dropped equally. For the SSV, a downward trend from $23.7 \%$ o to $7.9 \%$ o was evidenced, against $16 \%$ o to $8.4 \%$ o at national level, which shows a relative reduction of more than $66.7 \%$ at local level vs. $47.5 \%$ at national level (Figure 1).

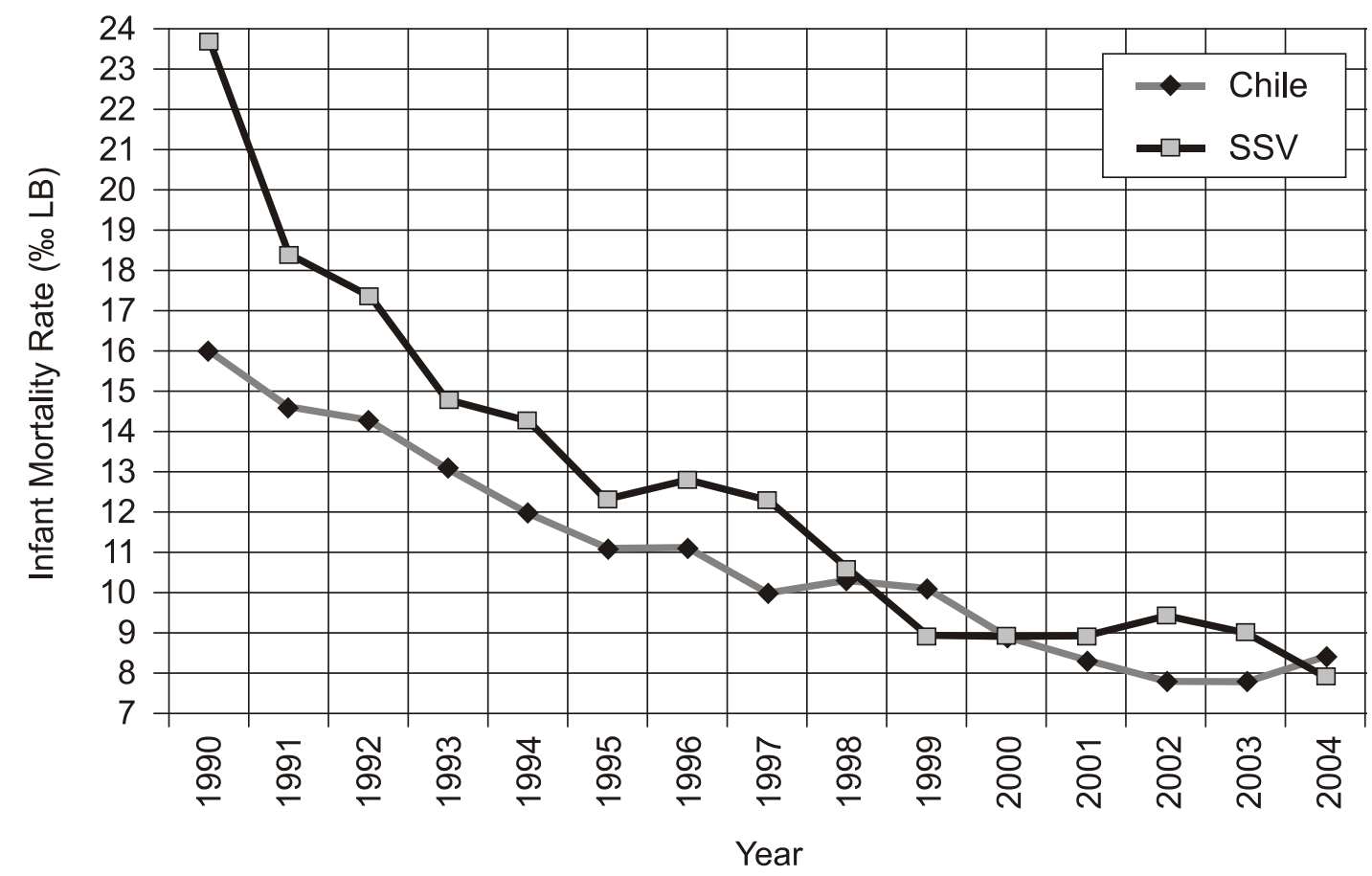

Figure 1 - Infant Mortality Rate 1990 - 2004 for Chile and for the Valdivia Health Service. Source: DEIS

Consequently, the gap observed at the start of the 1990's considerably decreased, mainly as from 1998. Similarly, at national as well as local level, the intensity of this decline slowed down from 1997 onwards. Regarding the neonatal mortality rate, despite greater variability at local level, with important increases for some years (1992 and 1994), the trend was downward, but generally continued to surpass national levels (Figure 2). In this case, the relative reduction at local level amounted to $67.5 \%$, against $36.5 \%$ at national level.

Finally, the early neonatal component reflects what was shown for neonatal mortality, with increases for the same years and mostly surpassing national rates (Figure
3). As from 1995, this rate evidenced a much more uniform behavior. As opposed to national levels, since 2002 , the local rate displayed a discrete drop.

In 2000 - 2004, 167 deaths occurred of infants younger than one year in the SSV area. Among specific causes of death, the three most important were causes deriving from birth or perinatal problems: Disorders related to length of gestation and fetal growth, ICD-10 codes P05 - P08 ( $n=29)$, Congenital cardiac malformations, codes Q20 - Q24 ( $n=23)$ and Intrauterine hypoxia and birth asphyxia, codes P20 and P21 $(n=15)$. 


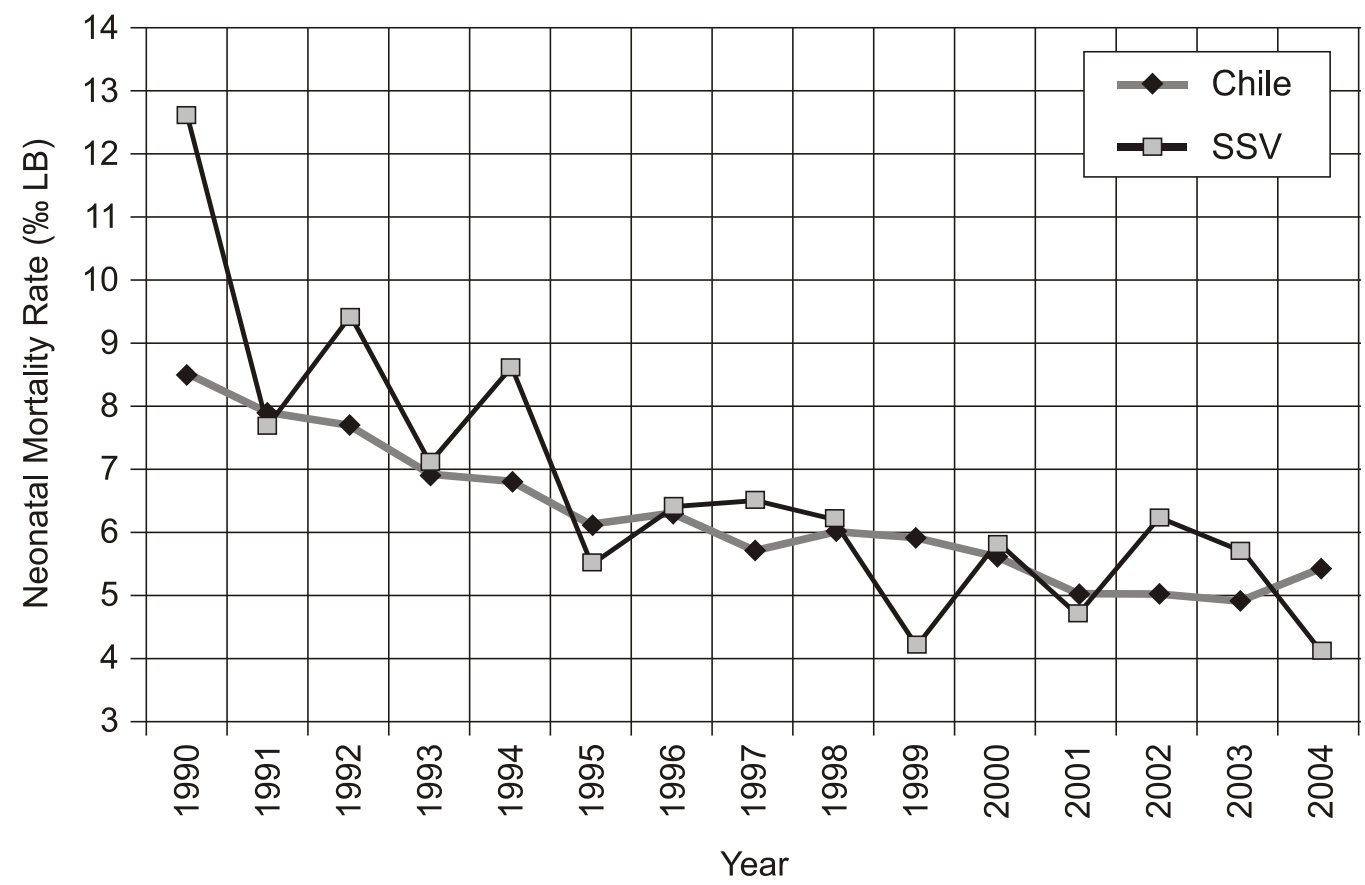

Figure 2 - Neonatal Mortality Rate 1990 - 2004 for Chile and for the Valdivia Health Service. Source: DEIS

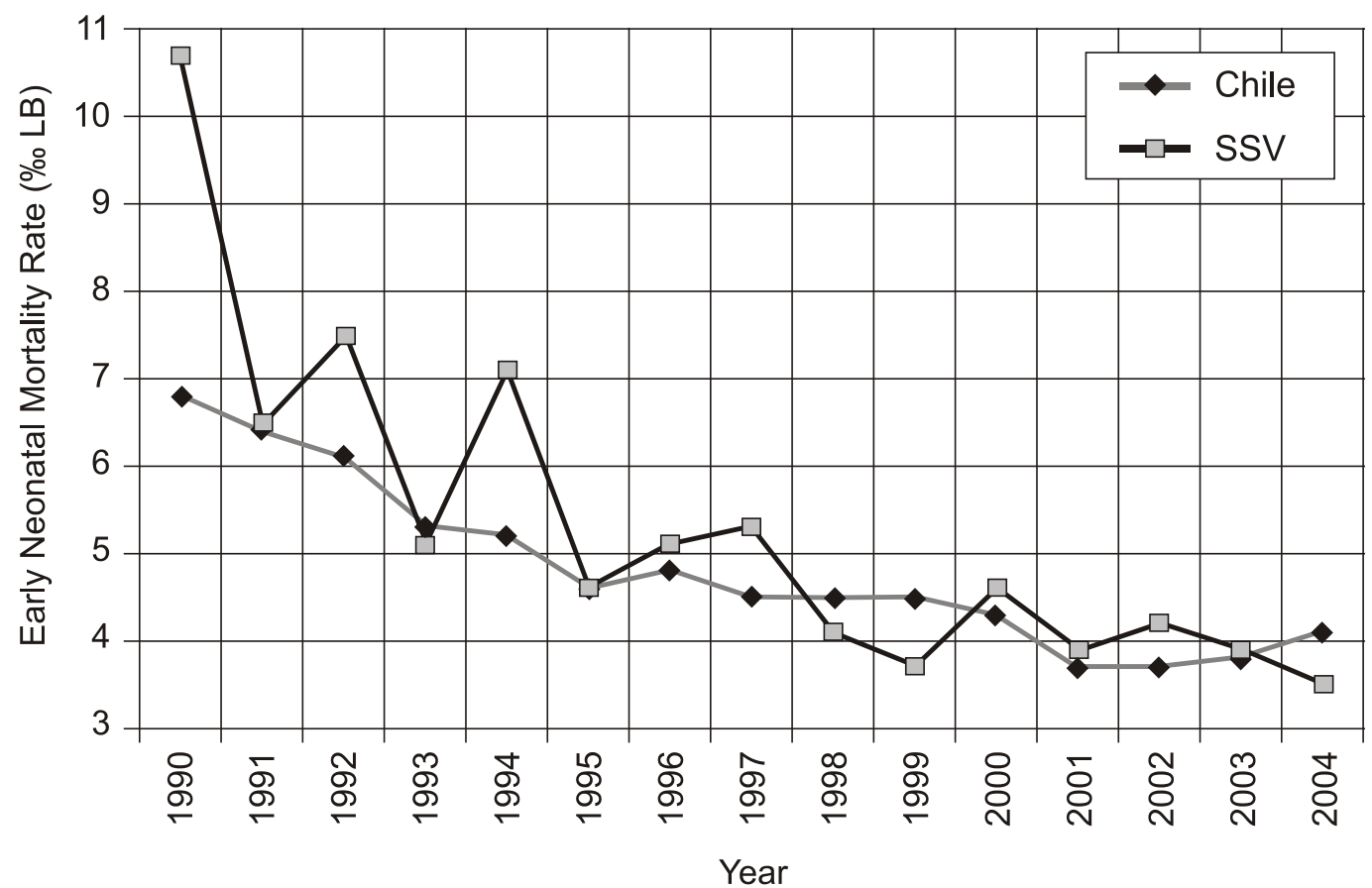

Figure 3 - Early neonatal mortality rate 1990 - 2004 in Chile and for the Valdivia Health Service (SSV). Source: DEIS

Regarding the infant population younger than 32 weeks and/or with very low birth weight, for the period 2000 - 2005, in the SSV area, 365 births were registered, with 47 to 68 births per year. At the SSV neonatal intensive care unit, in turn, 331 neonates with these characteristics were hospitalized, with an annual admission frequency ranging between 49 and 58 infants. Differences between recorded births and hospitalizations refer to infants who died at the delivery room immediately after birth and, on the other hand, to the probable transportation of neonates due to the lack of room in neighboring hospitals that depend on 
different health services in other cities. Nevertheless and coincidentally, higher birth and hospitalization rates for these infants were found as from 2002. In total, 53 deaths occurred among children with very low birth weight and/or at less than 32 weeks between 2000 and 2005, ranging between 6 and 11 per year. The mortality rate calculated based on available data varied, due to the small number of these births at local level, ranging between 88.2 and $200 \%$ of liveborns. Thus, these figures should be assessed cautiously in this context (Table 1).

Table 1 - Annual distribution of NICU hospitalizations, liveborns, neonatal deaths and mortality rates of neonates with very low birth weight and/or at less than 32 weeks at the Valdivia Health Service, 2000 - 2005

\begin{tabular}{ccccc}
\hline Year & $\begin{array}{c}\text { NICU hospitali- } \\
\text { zations < } 1500 \mathbf{g} \\
\text { and/or <32 w. }\end{array}$ & $\begin{array}{c}\text { Liveborns with } \\
\text { VLBW and/or } \\
<\mathbf{3 2} \mathbf{~ w . ~}\end{array}$ & Deaths & $\begin{array}{c}\text { Mortality } \\
\text { Rate* }^{*}\end{array}$ \\
\hline 2000 & 51 & 47 & 9 & 191,5 \\
2001 & 49 & 55 & 11 & 200,0 \\
2002 & 58 & 68 & 6 & 88,2 \\
2003 & 58 & 61 & 11 & 180,3 \\
2004 & 57 & 68 & 6 & 88,2 \\
2005 & 58 & 66 & 10 & 151,5 \\
Global & 331 & 365 & 53 & 145,2 \\
\hline
\end{tabular}

*Rate per thousand liveborns.

NICU: neonatal intensive care unit; VLBW: very low birth weight.

Source: DEIS; database of the Premature Follow-Up Program, SSV.
The causes of death recorded as the main diagnosis for the 53 deaths underline the large proportion of respiratory distress syndrome, code P22.0 (22.6\%), pulmonary hemorrhage, code P26.1 (18.9\%) and sepsis, codes P36.0 - P36.9 (17\%).

Figure 4 contrasts the mortality rate of the infants under analysis with the annual doses applied for pulmonary development (antenatal corticoids) as well as exogenous surfactant therapy. Taking the year 2000 as the baseline, an increase in mortality rates was observed in 2001, in line with a drop in corticoid and surfactant application rates. In 2002, an important drop in mortality coincided with the higher number of surfactant doses used and, in 2003, a new reduction in corticoid and surfactant doses coincided with increased mortality rates.

It should be specified that, during the study period, 12 infants were considered extremely premature, with an estimated gestational age below 25 weeks. Nine of them were born in 2005. In a way, and given the few cases observed at local level, these can exert important effects on the calculated rate.

Finally, the information related to modifications incorporated during 2000 - 2005 only shows important changes in the last two years, highlighting the purchasing and putting in practice of multi-parameter monitors, mechanical ventilators and massive use of peripherallyinserted central catheters at the NICU. In addition, no modifications were made in terms of human resource allocation, although high nursing turnover stood out.

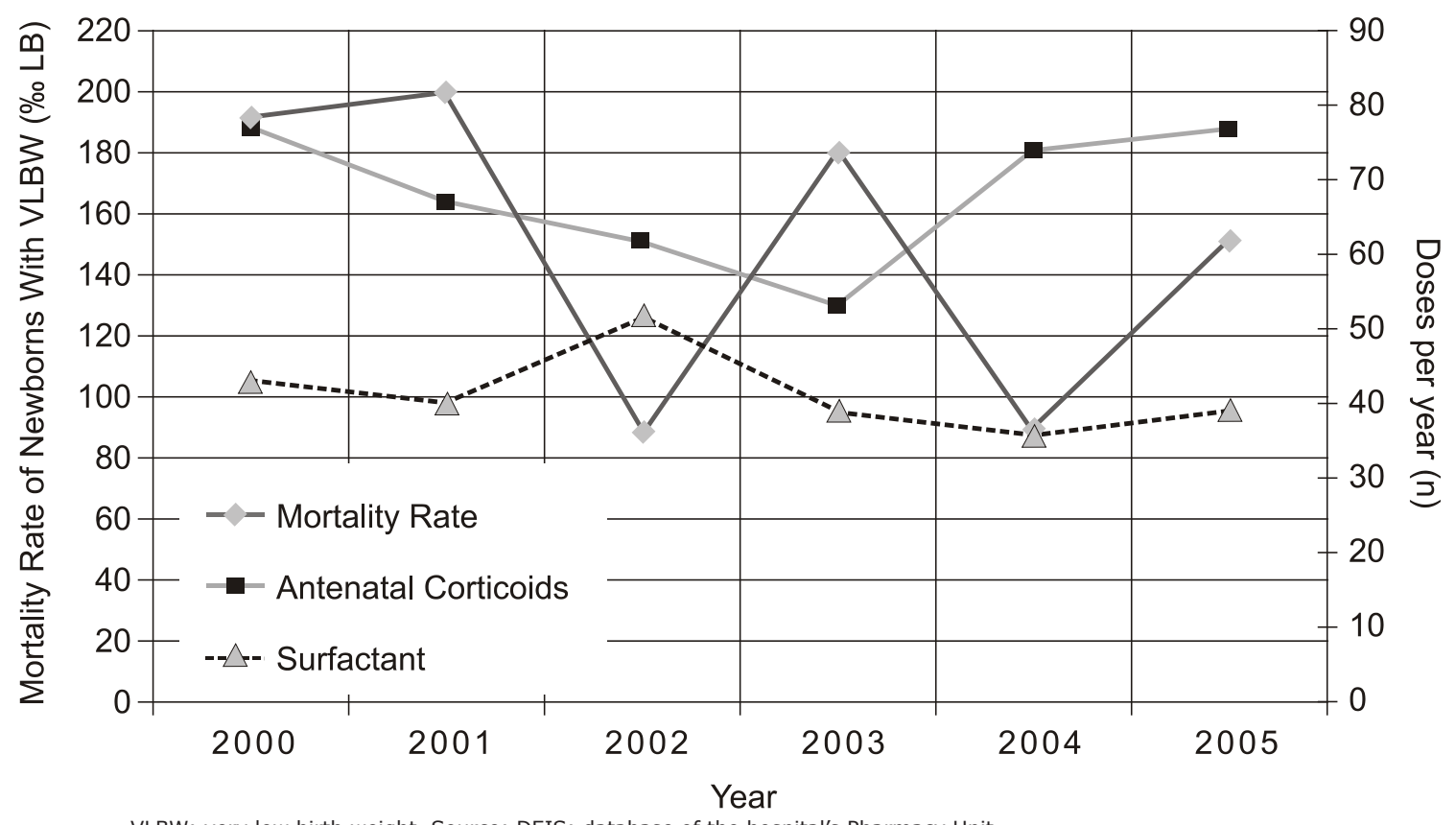

VLBW: very low birth weight. Source: DEIS; database of the hospital's Pharmacy Unit.

Figure 4 - Mortality Rate in neonates with very low birth weight and/or at less than 32 weeks between 2000 and 2005 and applied doses of antenatal corticoids and surfactants 


\section{Discussion}

The IMR reveals an important decrease since 1990, although the intensity of this drop has slowed down since 1998. In addition, differently from the previous decade, infant, neonatal and early neonatal mortality rates showed a more uniform behavior, although confirming the weighing of the effect of the neonatal component as the main contributor to the IMR. Also, the gap observed between national and local rates in the first years was notably reduced, with local rates even decreasing below national one in some years, as a result of a more intensive relative reduction. These results suggest that national policies have led to a massive spread in the implementation of equipment, resources in general and, mainly, access to pharmacological therapies like surfactant and antenatal corticoid. Thus, local results are in line with national rates.

The Neonatology unit at Hospital Clínico Regional Valdivia was redesigned and put in practice with modern technological resources, including the creation of the new hospital, which has been operating since 1995. This led to high architectural and equipment standards, including monitors, incubators and heated cribs, putting this unit at the frontline in the public sector in recent years. Thus, it is probable that the evidenced drops in neonatal and early neonatal mortality since that year are largely due to that situation.

This is consistent with reports from another national study ${ }^{(8)}$, which analyzed the period 1990 2000 and demonstrated an improvement in premature survival rates, as a result of the readjustment of care and strategies put in practice. On the other hand, contradictory data are found regarding the possible effect of unit size on mortality as, on the one hand, larger units, and hence with more beds, have showed lower neonatal mortality risk rates ${ }^{(11)}$, while no consistent relation with size has been established at others(12). Similarly, but regarding human resources, it has been demonstrated that allocating more neonatologists per number of births significantly reduces neonatal mortality ${ }^{(12)}$, as well as the qualification of specialized nurses and the infant/nurse relation, linked with lower neonatal mortality risks in premature neonates and with very low birth weight ${ }^{(13)}$.

Regarding the causes of death, respiratory distress syndrome and sepsis continue as the main problems, and pulmonary hemorrhage plays an important role. The first had already been described as the main morbidity and mortality problem in infants with very low birth weight and particularly with extremely low birth weight, where it rises up to $60 \%{ }^{(9)}$. Pulmonary hemorrhage, in turn, was recently highlighted as an important mortality risk factor in infants under $1500 \mathrm{~g} y$ and at less than 32 weeks of gestational age ${ }^{(14)}$. It should be mentioned though, that this comparison is based on distinct (proportion vs. rate) indicators but that, nevertheless, they show the risk condition associated with the described disorders.

Although, as a study of combined data, no inferences can be made about causal relations at individual level, these results suggest that antenatal corticoid and surfactant use exerts important effects, in line with large-scale reports in different series ${ }^{(15-16)}$. Particularly in the previous decade, surfactant use showed to be the main factor to bring down mortality rates in infants under $1500 \mathrm{~g}$ and, in turn, led to a reduction in these children's treatment $\operatorname{costs}^{(17)}$. Nevertheless, other factors exist that have impeded further reductions in mortality rates in this group. Among these, the number of premature infants of younger gestational ages and at the limits of feasibility has increased, which was observed locally as from 2003 and particularly in 2005, definitely affecting the mortality rate ${ }^{(14)}$.

Given the modifications in the profile of risk neonates and their current prognosis, today, premature infants and with very low birth weight are considered a priority, including their problems in the explicit health guarantee (EHG) regimen(7). Consequently, in subsequent years, it seems relevant to analyze other interventions and strategies put in practice in neonatal care, such as strategies linked with the sanitary reform for example, assessing the impact of EHG on neonates and premature delivery.

Like in all epidemiological studies, limitations exist that demand cautious evaluation of the results. It should be taken into account that, when comparing national and SSV data, the population in the latter particularly premature infants - was small, so that small variations in death rates caused important variations in the mortality rate. Although no specific mortality data were available for other care network centers regarding the characteristics studied here, in the global context of neonatal mortality, Valdivia shows no significant difference from other regions, although advances in mortality rates are observed in recent years, making the city's rates comparable with national levels.

The analysis of current scenarios permits a closer approach to the impact of interventions put in practice, as well as reorientations in strategies aimed at improving the survival and quality of life of premature children and at strengthening, correcting and outlining new health 
policies to reduce mortality. It is important for referral health centers in each region to have their own morbidity and mortality studies, to provide knowledge on their situation in comparison with other centers, optimizing their resources according to the local problem and undertaking benchmarking actions to improve local care through formulae tested in other places ${ }^{(18)}$. Consequently, if these measures are sufficiently effective, they will entail a profound economic impact, which is vital in developing countries like Chile.

\section{References}

1. Kaempffer A, Medina E: Mortalidad infantil reciente en Chile: Éxitos y desafíos. Rev Chil Pediatr. 2006;77:492-500.

2. Águila A, Muñoz H: Tendencia de la natalidad, mortalidad general, infantil y neonatal en Chile desde el año 1850 a la fecha. Rev Med Chil. 1997;125:1236-45.

3. Szot J: Mortalidad en el menor de 1 año por causas externas, Chile, 2000. Rev Chil Pediatr. 2003;74:492-8. 4. Lawn JE, Cousens S, Zupan J: 4 million neonatal deaths: when? Where? Why? Lancet. 2005;365:891900.

5. Zupan J, Aahman E. Perinatal mortality for the year 2000: estimates developed by WHO. Geneva: World Health Organization; 2005.

6.-Szot J. Mortalidad infantil en Chile: 1989-1998. Rev Chil Pediatr. 2002;73:164-8.

7. D'Apremont I: Redes de Investigación Neonatal. Medwave. 2003;3(10). [acceso 12 dic 2009]. Disponível em: http://www.medwave.cl/atencion/infantil/ FUDOC2003/2FUDOC2003/4.act).

8. Gonzalez R, Merialdi M, Lincetto O, Lauer J, Becerra C, Castro R, et al. Reduction in neonatal mortality in Chile between 1990 and 2000. Pediatrics. 2006;117:e949-e54.

9. Morgues M, Henríquez MT, Tohá D, Vernal P, Pittaluga $E$, Vega $S$, et al. Sobrevida del niño menor de $1500 \mathrm{~g}$. en Chile. Rev Chil Obstet Ginecol. 2002;67:100-5.

10. Aschengrau A, Seage III G. Essentials of Epidemiology in Public Health. 2th ed. Sudbury (MA): Jones and Barlett Publishers; 2008.

11. Phibbs CS, Bronstein JM, Buxton E, Phibbs RH. The effects of patient volume and level of care at the hospital of birth on neonatal mortality. JAMA. 1996;276:1054-9. 12. Goodman DC, Fisher ES, Little GA, Stukel TA, Chang $\mathrm{CH}$, Schoendorf KS: The relation between the availability of neonatal intensive care and neonatal mortality. $\mathrm{N}$ Engl J Med. 2002;346:1538-44.
13. Hamilton KE, Redshaw ME, Tarnow-Mordi W: Nurse staffing in relation to risk-adjusted mortality in neonatal care. Arch Dis Child Fetal Neonat. 2007;92:F99-F103.

14. Barría RM, Pino $P$, Becerra C. Mortalidad en prematuros tratados con surfactante exógeno. Rev Chil Pediatr. 2008;79:36-44.

15. Ghodrat M. Lung surfactants. Am J Health Syst Pharm. 2006;63:1504-21.

16. Crowley PA. Antenatal corticosteroid therapy: a meta-analysis of the randomized trials, 1972 to 1994. Am J Obstet Gynecol. 1995;173:322-35.

17. Schwartz RM, Luby AM, Scanlon JW, Kellogg RJ. Effect of surfactant on morbidity, mortality, and resource use in newborn infants weighing 500 to $1500 \mathrm{~g}$. N Engl J Med. 1994; 330:1476-80.

18. Llanos A. Morbilidad y mortalidad del RN menor de $1.500 \mathrm{~g}$ : Experiencia de un hospital regional de la red internacional Vermont Oxford. Rev Chil Pediatr. $2006 ; 77: 363-74$. 